\title{
ELECTRONIC RESOURCE AND SERVICES GATEWAYS: A COMPARATIVE STUDY OF GOOGLE AND YAHOO
}

\author{
UMESHA NAIK
}

Assistant Professor, Department of Library and Information Science, Mangalore University, Mangalore, Karnataka, India

ABSTRACT
Nowadays, electronic tools, resources and services are very essential for the users to acquire, retrieve, and
disseminate the required tools and information. The Google and Yahoo electronic resource management system is a web-
based system, that manages the tools, services and licensing, of electronic resources and services. Google and
Yahoo Multinational Corporation, that provide Internet and ICT related products and services. The objective is to evaluate
the popular application available in both Google and Yahoo information systems. This study is attempting to evaluate the
effectiveness of electronic resources and services, in Google and Yahoo system, on the basis of tools resources, and services
available at both sites. This article also highlights the popular information resources, tools, services and other active
programs, provided by the Google and Yahoo companies, to their end users. These tools also support as a gateway for
finding, downloading and uploading the information in a proper manner.
KEYWORDS: E-Resources, E-Services, E-Tools, E-Gateways, Google, Yahoo, Internet Tools and Web Services

Received: Oct 20, 2016; Accepted: Nov 30, 2016; Published: Dec 20, 2016; Paper Id.: IJLSRDEC20169

\section{INTRODUCTION}

The e-resources include information communication technology and any equipment or interconnected system, or subsystem of equipment that is used in the creation, conversion, duplication, or delivery of data or information. The Google and Yahoo provide major e-resources and services, to the public and few resources and services are free of cost. Google and Yahoo, both are the e-resources and services portal, that incorporates a search engine and a directory of World Wide Web sites, organized in a hierarchy of topic categories. The ICT trends library like. It also provides one of the best ways to search the web, for a given topic for better result.

\section{ELECTRONIC INFORMATION RESOURCES AND SERVICES}

The rapid growth of new technologies has changed the communication process, and reduced the cost of communication for individuals. Electronic information resources can be defined as the electronic representation of information, which can be accessed via electronic system and computer network. Libraries are increasingly considering, if and how to provide access to relevant internet resources, for their users. Library and information centers have transformed into digital and virtual libraries, where library materials have changed into e-resources, leading to the increase in the global dissemination of information. The e-resources such as e-journals, e-books, edatabases, web resources, and others are made easier, to be accessible in remote areas as well as desktop access. Accessing electronic resources is as good as the resources, that can afford the skill to work with the tools efficiently, while the network communications that supports fast and suitable connections. 


\section{Google}

Google is an American multinational technology company, specializing in Internet-related services and products, that include online advertising technologies, search, cloud computing, software, and hardware. The world's biggest internet company Google, is celebrating its 18th birthday. In the present scenario, Google is one of the world's largest data storage company, with servers to store people's work, photos, emails and everything else. Larry Page and Sergey Brin, the Ph.D. students of Stanford University, California were started the Google, in 1996. Overall activities of Google are the main Achievements, as follows;

- Google launches the Gmail service on 1st April 2004, with 1 GB of free storage

- The social networking site of Orkut was launched in the year 24th January 2004, with 45 languages.

- $\quad$ The video sharing site, YouTube was launched in the year 14th February 2005.

- There are 209 mergers and acquisitions subsidiaries, available within Google.

Yahoo

Yahoo was founded, by Jerry Yang and David Filo, in the year January 1994, and was incorporated on March 2, 1995. It is an American multinational technology company, headquartered in Sunnyvale, California. One of the pioneers of early internet era, in the 1990's. It was known for its Web portal, search engine and related services, including Directory, Mail, News, Finance, Groups, Answers, advertising, mapping, video sharing, and many more. Overall activities of yahoo and the main achievements are as follows;

The Yahoo Mail Plus provides accounts with a capacity of 2 GB of data storage. Later, in 2007, Yahoo took out the storage meters and made the storage limit unlimited. Yahoo has upgraded its mail service, by providing various tools and add-ons, such as creating an avatar, changing the color of mail window, various themes and much more.

Yahoo is regarded as the most visited websites on the internet, by Web traffic analysis companies Comscore, Alexa Internet and Netcraft, with more than 130 million unique users.

\section{OBJECTIVES OF THE STUDY}

The main objectives of the study are;

- To find out the different tools and services of Google and Yahoo companies

- To identify the popular tools and services and their status;

- To discuss web-based resources offered through the end users;

- To analyze the origin, status and existing functions of theses web-based services; and

- To suggest the new approaches for effective use of web-based services.

\section{BACKGROUND}

\section{Literature Review}

Efforts were made to use available original articles/abstracts, for the review. Many numbers of studies have been conducted on the overall product and services, its awareness of Google and Yahoo companies. ChangeWaveResearch 
(2005), provides the pin to pin general online usage trends, of both Google and Yahoo products and services.

The importance of three electronic information products and their services, highlighted by Peter \& Finlayson (2005), on their book entitled "How to Make Money Online with eBay, Yahoo!, and Google". They have clearly mentioned that, the eBay is the world's most important online marketplace, Yahoo, is the e-commerce tool to manage their online sales, and Google is a business needs traffic. Google and the other "Pay Per Click" advertising systems, can help us to generate that traffic. Past research in India and other country has often focused on:

Google vs Yahoo!: The Importance of Brand and Design (Bunny foot, 2003).

Home Online Usage: Yahoo vs. Google: Head-to-Head Fight Continues Between The Two Online Heavyweights (Change Wave Research, 2005).

Google vs Yahoo (Clippingpathhouse.com, 2014).

Yahoo Vs Google (CYBION, 2008).

Google vs Yahoo: Difference and Comparison (Diffen, 2014).

Google and Yahoo: Their Similarities and Distinctions (Fita, 2012).

18 facts that you didn't know about Google, on its 18th birthday (Independent, 2016).

A Comparison of Google and Yahoo: Which is More Cost Effective, When Using Sponsored Links for Small Companies? (Kennedy \& Kennedy, 2009).

Precision and Relative Recall of Search Engines: A Comparative Study of Google and Yahoo (Kumar \& Prakash, 2009).

Google vs. Yahoo! Interface Design (Luke, 2005).

Over 101 Google products and services, you probably don’t know (Mohan, 2014).

How to use Internet Tools and Services (Naik \& Shivalingaiah, 2008).

Top 10 Yahoo! Properties (Readwrite, 2007).

Digital Library Services: A Comparative Study of Google and Yahoo Technology (Sasikala, Joselyn, Poornima \& Vennila, 2011).

List of Google products (Wikipedia. 2016).

List of Yahoo! -owned sites and services (Wikipedia, 2015).

\section{RESEARCH METHODOLOGY}

Research is a systematic process of collecting, analyzing the data on any specific subject and to interpret the results meaningfully, for common understanding. The study identified the internet based electronic information resource gateways, and the comparative study of Google and Yahoo products and services, only. In this study, the only two popular web based service providers have been included. The information about these products and services was retrieved from the internet. The methodology is a content analysis, of the websites of the Google and Yahoo only. There were more web based services, offered by some other companies, but this study has focused on categories like, general information about 
products, service, status, and use. The content analysis work was done during January to November, 2016. The following are the list of electronic information resource gateways, selected for the study:

Table 1: Selected E-Resource Gateways of Google and Yahoo

\begin{tabular}{|l|l|l|c|c|}
\hline S.. No. & \multicolumn{1}{|c|}{ e-Resource Gateways } & Emblem & Founded & $\begin{array}{c}\text { Rank from } \\
\text { Alexa }\end{array}$ \\
\hline 1 & Google & Google & 1997 & 1 \\
\hline 2 & Yahoo & YAHOO & 1995 & 5 \\
\hline
\end{tabular}

\section{SCOPE AND LIMITATIONS}

In order to realize the objectives, the study has been restricted only Google and Yahoo's, online products and services. The selection of study Electronic Information Resource Gateways of Google and Yahoo, was based on its availability, functions, status and the use for the active users. The tools and services, considered for the present study fall under Google and Yahoo product and services only. No sampling method was adopted in view of comprehensive coverage and consistency, in interpretations of the findings of the study. The study deals with internet related tools and services of Google and Yahoo, available during January 2016 to November 2016. There are a number of sites available on the internet, but the investigator selected only two popular sites, for better results.

\section{PRESENTATION AND DISCUSSION OF FINDINGS}

Both Google and Yahoo are two major internet industries, striving for their name to be at the top of the chart. Both Google and Yahoo provide almost the same services like mail, search engines, weather forecast, news and other services, for the ease of their users on a single website.

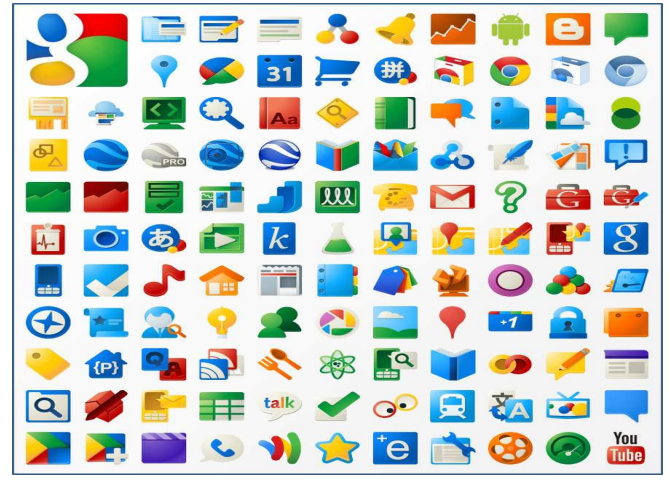

Figure 1: Google Products and Services

\begin{tabular}{|c|c|}
\hline - $\underline{\text { Yaho0! Advertising }}$ & - $\underline{\text { Yahoo! Music }}$ \\
\hline - $\underline{\text { Yahoo! } \text { Answers }}$ & - Yahoo! News \\
\hline - $\underline{\text { Yahoo! Autos }}$ & - Yahoo! Originals \\
\hline - Yahoo! Developer Network & - Yahoo! Parental Controls \\
\hline - $\underline{\text { Yahoo! Finance }}$ & - $\underline{\text { Yahoo! Research }}$ \\
\hline - $\underline{\text { Yahoo! GeoPlanet }}$ & - Yahoo! Search \\
\hline - Yahoo! Groups & - Yahoo! Search Marketing \\
\hline - Yahoo! Homes & - Yahoo! Security Center \\
\hline - $\underline{\text { Yahoo! Local }}$ & - Yahoo! Shopping \\
\hline - Yahoo! Mail & - Yahoo! Sports \\
\hline - Yahoo! Messenger & - Yahoo! Th? gi? i sao \\
\hline - $\underline{\text { Yahoo! Mobile }}$ & - Yahoo! Travel \\
\hline - $\underline{\text { Yahoo! Movies }}$ & - Yahoo! TV \\
\hline
\end{tabular}

Figure 2: Yahoo Services

The Figure 1 and 2, focus on product and services, available on Google and Yahoo companies. Here, the icons are highlighted Google and hyperlinks highlighting in Yahoo products and services. Once again, the Google has more than Yahoo products and services.

Table 2, shows the major products and services, and their detailed tools, features, and functions, of both Google and Yahoo. But, Google has always been way ahead than Yahoo, by providing a bit of more convenience and better services results. Google is the number 1 search engine, whereas Yahoo manages for 2nd place, worldwide. Google provides services like Books, Ad words, Admob, which are missing in Yahoo. Although, Yahoo, as they also have several products and services, which are missing in Google, but keeping it short and simple, Google is the best service oriented tools, 
compared to Yahoo.

Table 2: Major Products and Services by Google and Yahoo

\begin{tabular}{|c|c|c|}
\hline \multirow[b]{2}{*}{ Products and Services } & Google & YAHOO! \\
\hline & $\begin{array}{c}\text { Global Organization of } \\
\text { Oriented Group Language } \\
\text { of Earth }\end{array}$ & $\begin{array}{l}\text { Yet Another Hierarchical } \\
\text { Officious Oracle }\end{array}$ \\
\hline Type of site & Public & Public \\
\hline Started & September 1998 & January 1994 \\
\hline Traded as & NASDAQ: GOOG & NASDAQ: YHOO \\
\hline Money earned & US\$ 59.82 billion (2013) & US\$ 4.968 billion (2015) \\
\hline Employees & 47,756 & 10,400 \\
\hline Localized \& regional domains & 198 & 59 \\
\hline Products and services & 42 & 34 \\
\hline List of mergers and acquisitions & $\begin{array}{l}201 \\
(2001-2016)\end{array}$ & $\begin{array}{l}114 \\
(1997-2015)\end{array}$ \\
\hline Purchase or Free & Free & Free \\
\hline Company type & Public & Public \\
\hline $\begin{array}{l}\text { Error! Bookmark not defined. as on } \\
\text { Sep. } 2016\end{array}$ & 1 & 5 \\
\hline SSimilarWeb as on Sep. 2016 & 1 & 5 \\
\hline Founder & Larry Page and Sergey Brin & Jerry Yang and David Filo \\
\hline Begin & September 7. 1998 & March 1, 1995 \\
\hline Alerts & Google & Y! \\
\hline Answer & GoOglem & YAETOO! \\
\hline Blogs & Google & 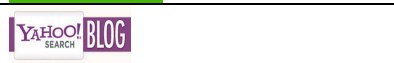 \\
\hline Book Search & Google & No \\
\hline Bookmarks & 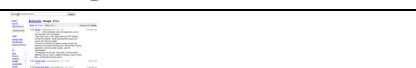 & 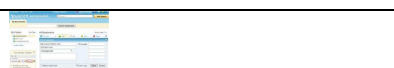 \\
\hline Browser & Google & YAHOO! \\
\hline Calendar & Google & TZMAOOI- \\
\hline Directory & 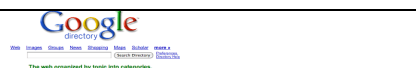 & TaHOO, onReCTORY \\
\hline Documents & $\equiv$ & - \\
\hline Drive & $\lambda$ & \\
\hline Emblem & Google & YAFOO! \\
\hline Employees & $53,600(\mathrm{Q} 22014)$ & $12,200($ Dec 2013) \\
\hline Finance & Google finance & 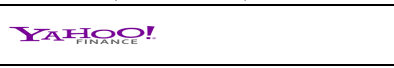 \\
\hline Fire Eagle & - & fire eagle \\
\hline Groups & Google & $\underset{\text { GROUIS }}{\mathrm{YAO}}$ \\
\hline Groups & 2 & $\underset{\text { GROUPS }}{\text { YAHOO! }}$ \\
\hline Image Search & Google & 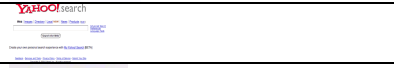 \\
\hline Mail & GMaili $(15 \mathrm{~GB})$ & YAHOO! $_{\text {MAlL }}(1 \mathrm{~TB})$ \\
\hline Maps & 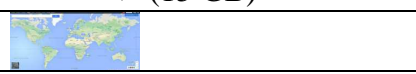 & 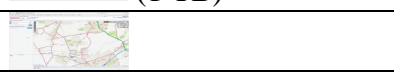 \\
\hline Movies & > Google play & \\
\hline
\end{tabular}




\begin{tabular}{|c|c|c|}
\hline \multirow[b]{2}{*}{ Products and Services } & Google & YAHOO! \\
\hline & $\begin{array}{c}\text { Global Organization of } \\
\text { Oriented Group Language } \\
\text { of Earth }\end{array}$ & $\begin{array}{c}\text { Yet Another Hierarchical } \\
\text { Officious Oracle }\end{array}$ \\
\hline News & Google & YAHOO! \\
\hline Page Creator & Google & $=-\bar{B}$ \\
\hline Page Ranking Facility & Yes & No \\
\hline Scholar & Googłe & Yartoolsearch \\
\hline Social Network & Googlet YouTube & HAx E \\
\hline Started Year & March 1996 & January 1994 \\
\hline Translate & 竞A & YAHOO! TRANSLITERATION \\
\hline Type of Access & Public & Public \\
\hline Users (Monthly) & 2 Trillion & 1 Billion \\
\hline Web Album & E Picasa" wob Alloums & flickr $^{:}$ \\
\hline Website & www.google.com & www.yahoo.com \\
\hline Contacts & Yes & Yes \\
\hline Slogan & Don't be evil & Do you Yahoo? \\
\hline Free / Commercial & Free & Free \\
\hline Headquarters & $\begin{array}{l}\text { Mountain view, California, } \\
\text { USA }\end{array}$ & Sunnyvale, California, USA \\
\hline Instant Message & Yes & Yes \\
\hline Download & Yes & Yes \\
\hline Company Type & Public & Public \\
\hline Profile & Yes & Yes \\
\hline Themes & No & Yes \\
\hline Games & No & Yes \\
\hline Finance Portal & Yes & Yes \\
\hline Job Site & No & Yes \\
\hline Video & Yes & Yes \\
\hline Services & Free & Free \\
\hline
\end{tabular}

E-resources are becoming more and more important, for the academic community. The study highlights the resources and services available on both Google and Yahoo gateways, based on the Google Dashboard like web, Business, Media, Geo, Specialized Search, Home \& Office, and Social. Google has 204 product and services (Mohan, 2016), and Yahoo listed only 26 products and services (Wikipedia, 2015). The investigator selected only few popular products and services.

Table 2: Product and Services of Google and Yahoo

\begin{tabular}{|c|c|c|c|c|c|c|}
\hline Category & Name & Emblem & Found & Name & Emblem & Found \\
\hline \multirow{2}{*}{ Web } & Web Search & 3 & 1997 & Web Search & & 1995 \\
\hline & Bookmarks & & 2005 & Bookmarks & YАНОО! & 2005 \\
\hline \multirow{3}{*}{ Business } & $\begin{array}{l}\text { Google Apps for } \\
\text { Work / G Suite }\end{array}$ & & 2006 & $\begin{array}{l}\text { Yahoo's } \\
\text { Aabaco Small } \\
\text { Business }\end{array}$ & YAHOO! & 1998 \\
\hline & AdSense & 8 & 2003 & Yahoo's Media & 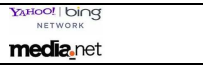 & 2015 \\
\hline & AdMob & & 2009 & Yahoo Mobile & & 2007 \\
\hline
\end{tabular}




\begin{tabular}{|c|c|c|c|c|c|c|}
\hline \multicolumn{7}{|c|}{ Google } \\
\hline Category & Name & Emblem & Found & Name & Emblem & Found \\
\hline \multirow{6}{*}{ Media } & Books & & 2004 & - & - & - \\
\hline & Image Search & $\mathrm{O}^{\circ}$ & 2001 & Image Search & $Y$ & 2008 \\
\hline & News & $\overline{6}$ & 2002 & Yahoo News & YAHOO! & 1996 \\
\hline & Google Videos & 9313 & 2005 & Yahoo! View & YAHOO! & 2006 \\
\hline & Google Photos & $t$ & 2015 & Yahoo Photos & 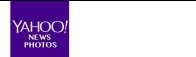 & 2000 \\
\hline & Google Cardboard & 0 & 2014 & - & - & - \\
\hline \multirow{3}{*}{ Geo } & Google Maps & 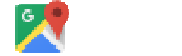 & 2005 & Yahoo! Maps & YAHOOI & 2002 \\
\hline & Google Earth & 5 & 2001 & - & - & - \\
\hline & Custom Search & Google & 2006 & Yahoo! BOSS & $\begin{array}{l}\text { Xangol } \\
\text { Bimss }\end{array}$ & 2012 \\
\hline \multirow{3}{*}{$\begin{array}{l}\text { Specialized } \\
\text { Search }\end{array}$} & Google Scholar & 8 & 2004 & $\begin{array}{l}\text { Yahoo } \\
\text { Research }\end{array}$ & YA & 2004 \\
\hline & Google Trends & Google Trends & 2006 & - & - & - \\
\hline & Google Flights & - & 2011 & 2011 & TRAVEL & 1997 \\
\hline \multirow{11}{*}{$\begin{array}{l}\text { Home } \quad \& \\
\text { Office }\end{array}$} & Gmail & M & 2004 & Yahoo Mail & YAHOO! MAIL & 1997 \\
\hline & Google Drive & 4 & 2012 & - & - & - \\
\hline & Google Docs & E & 2006 & - & - & - \\
\hline & Google Sheets & 田 & 2006 & - & - & - \\
\hline & Google Slides & E & 2006 & - & - & - \\
\hline & Google Forms & 1 & 2006 & - & - & - \\
\hline & Google Drawings & 0 & 2010 & - & - & - \\
\hline & Sites & 圆 & 2008 & $\begin{array}{ll}\text { Yahoo! } & \text { Site } \\
\text { Explorer } & \\
\end{array}$ & $=$ & 19902011 \\
\hline & Google Calendar & 31 & 2006 & $\begin{array}{l}\text { Yahoo } \\
\text { Calendar }\end{array}$ & 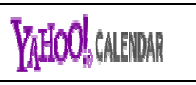 & 1998 \\
\hline & Translate & $G_{x}$ & 2006 & - & - & - \\
\hline & Hangouts & 67 & 2013 & $\begin{array}{l}\text { Yahoo } \\
\text { Messenger }\end{array}$ & $\because$ YAHOO! & 1998 \\
\hline \multirow{4}{*}{ Social } & Google+ & G+ & 2011 & Yahoo! $360^{\circ}$ & $\mathrm{Y} A \mathrm{HOO} / 360^{\circ}$ & 2005 \\
\hline & Blogger & $\theta$ & 2003 & Yahoo! $360^{\circ}$ & YAHOO/, $360^{\circ}$ & 2005 \\
\hline & Groups & 2 & 2001 & Group & YAHOO! & 1998 \\
\hline & Spaces & $\rightarrow$ & 2016 & - & - & - \\
\hline
\end{tabular}

Table 3, shows that, based on the categories of products and service, the Google has more number of products and services. Under media category book and Cardboard, Geo category Earth/Map, specialized search trends, home and office related Translator, Drive, Doc, Sheet, Form, Slides, and Drawings, are not available on Yahoo. 
Table 3

\begin{tabular}{|l|l|l|}
\hline \multicolumn{1}{|c|}{ Basis } & \multicolumn{1}{c|}{ Google } & Yahoo \\
\hline Nature & Simple & Complicated \\
\hline Relevant & More relevant & Less relevant \\
\hline Search technology & Similar to yahoo & Similar to Google \\
\hline Ranking links & Inbound links differently & Inbound links differently \\
\hline Redundancy & Redundancy present & Less redundancy \\
\hline Update & Update more frequently & Update less frequently \\
\hline Algorithm & More concern about off-page factors & Much concern about on-page factors \\
\hline Page rank & Have own page ranking features & $\begin{array}{l}\text { Doesn't have a page ranking } \\
\text { features? }\end{array}$ \\
\hline Index the sites & More Faster & Faster \\
\hline Search Engines & Much concern about off-page & Much concern about on-page factors \\
\hline Decentralization and Redundancy & Yes & No \\
\hline
\end{tabular}

\section{FINDINGS}

Both, Google and Yahoo are the web based service providers, but yahoo has received criticism for funding spy and advertisement technologies. In this case, advertising from Yahoo's clients appears on-screen in pop-ups. Google has been criticized for many of its new services, like Book Search's effort to digitize millions of books and make the full text searchable, has led to copyright disputes with the Authors Guild. Geographic details, provided by Google Earth's satellite imaging have resulted in disputes with governments, who assert that, terrorists can get the full details of landmarks and their surrounding areas.

\section{CONCLUSIONS}

In conclusion, the advanced technology behind both Google and Yahoo is very similar, but Google and Yahoo rankings are different. It is obvious that, Google has some most important tools like search engine to enter and achieve high positions, for competitive keywords. But Yahoo has recently changed its policy and is now harder to manipulate, and to its merit also holds the most accurate back link count. Yahoo is more complicated and advertiser-focused. Both the companies have internet tools and services, in their product and services list, but Google is number one in a search engine and Yahoo is very popular in e-mail services, because it is older than Google. This article focused on the popular tools and services, provided to the public, and how the users access its benefits for their day to day work.

\section{REFERENCES}

1. Armstrong, E. A., Croft, V. F., Kok, V. T., \& lener, E. F. (2003). Electronic Resources Access: Issues and Resolutions in Two Academic Libraries. 4th International Conference of Animal Health Information Specialists Retrieved 1-7-2014, from http://research.wsulibs.wsu.edu/xmlui/handle/2376/2025

2. Bunnyfoot, U. (2003). Google v Yahoo!: The Importance of Brand and Design. Retrieved 11-11-2016, from http://www.hansonexperience.com/blog/files/GooglevYahoo1.pdf

3. Change Wave Research. (2005). Home Online Usage: Yahoo vs. Google: Head-to-Head Fight Continues Between The Two Online Heavyweights. Retrieved 1-11-2016, from http://www.changewave.com/

4. Clippingpathhouse.com. (2014). Google vs Yahoo Retrieved 20-8-2016, from http://www.clippingpathhouse.com/blog/googlevs-yahool

5. CYBION. (2008). Yahoo Vs Google. 20-7-2016, from www.veille.com/IMG/pdf/Cybion-Yahoo-Google.pdf 
6. Diffen. (2014). Google vs Yahoo: Difference and Comparison. 21-8-2016, from http://www.diffen.com/difference/Google_vs_Yahoo

7. Fita, M. (2012). Google and Yahoo: Their Similarities and Distinctions from http://www.brandignity.com/2012/08/googleand-yahoo-their-similarities-and-distinctions/

8. Global Network Initiative. (2014). Public Report on the Independent Assessment Process for Google, Microsoft, and Yahoo. Retrieved 1-11-2016,

from https://globalnetworkinitiative.org/sites/default/files/GNI\%20Assessments\%20Public\%20Report.pdf

9. Independent. (2016). 18 facts that you didn't know about Google, on its 18th birthday. Retrieved 1-11-2016, from http://www.independent.co.uk/life-style/gadgets-and-tech/news/when-is-googles-birthday-facts-doodle-how-old-internetcompany-search-a7331591.html

10. Kennedy, K., \& Kennedy, B. B. (2009). A Comparison of Google and Yahoo: Which is More Cost Effective When Using Sponsored Links for Small Companies? CS-BIGS, 2 (2), 114-119.

11. Kumar, B. T. S., \& Prakash, J. N. (2009). Precision and Relative Recall of Search Engines: A Comparative Study of Google and Yahoo. Singapore Journal of Library \& Information Management 38, 124-137.

12. Luke, W. (2005). Google vs. Yahoo! Interface Design. Retrieved 17-11-2014, from http://www.lukew.com/fflentry.asp?189

13. Mohan, M. (2014). Over 101 Google products and services you probably don't know. Retrieved 1-7-2014, from http://www.minterest.org/google-products-services-you-probably-dont-know/

14. Mohan, M. (2016). Over 201 Google Products \& Services You Probably Don't Know. Retrieved 20-11-2016, from http://www.minterest.org/google-products-services-you-probably-dont-know/

15. Mohanty, R., \& Chudamani, K. S. (2008, February 28-29 \& March1, 2008). A Comparative Study of Google and Yahoo Web Resources on the Search term "Physics India. Paper presented at the 6th International CALIBER-2008, University of Allahabad, Allahabad.

16. Naik, U., \& Shivalingaiah, D. (2004). Web Search Engines: Search Strategies. Paper presented at the Second PLANNER 2004, Manipur University, Manipur.

17. Naik, U., \& Shivalingaiah, D. (2008). Comparative Study of Web 1.0, Web 2.0 and Web 3.0. Paper presented at the 6th International CALIBER 2008, University of Allahabad, Allahabad.

18. Naik, U., \& Shivalingaiah, D. (2008). How to use Internet Tools and Services. Paper presented at the International Conference of Asian Special Libraries (ICoASL 2008), India Islamic Cultural Centre, New Delhi.

19. Paananen, A. (2012). Comparative Analysis of Yandex and Google Search Engines. Helsinki Metropolia University of Applied Sciences, Helsinki.

20. Peter, K., \& Finlayson, J. K. (2005). How to Make Money Online with eBay, Yahoo!, and Google. New York: McGraw-Hill Osborne Media.

21. Readwrite. (2007). Top 10 Yahoo! $\quad$ Properties. Retrieved $1-7-2014$, from http://readwrite.com/2007/07/30/top_10_yahoo_properties

22. Sasikala, V., Joselyn, Poornima, A., \& Vennila. (2011). Digital Library Services: A Comparative Study of Google and Yahoo Technology. Retrieved 10-7-2014, from http://14.139.186.108/jspui/bitstream/123456789/2758/1/Sasikala.pdf

23. Segev, E., \& Ahituv, N. (2010). Popular Searches on Google and Yahoo!: A "Digital Divide” in Information Uses? The 
Information Society, 26, 17-37.

24. Shivalingaiah, D., \& Naik, U. (2009). Semantic Web Tools: An Overview. Paper presented at the 7th International CALIBER 2009 Pondicherry University, Puducherry.

25. Wikipedia. (2015). List of Yahoo! -owned sites and services. Retrieved 5-11-2016, from http://en.wikipedia.org/wiki/List_of_Yahoo\%21-owned_sites_and_services

26. Wikipedia. (2016). List of Google products. Retrieved 1-11-2016, from https://en.wikipedia.org/wiki/List_of_Google_products 